\title{
THE RARE AND ENDANGERED ORCHID CYPRIPEDIUM CALCEOLUS L.IN CROATIA - REFOUND IN GORSKI KOTAR (WEST CROATIA) AFTER 126 YEARS
}

\section{Marta Justić ${ }^{1 *}$, Marija Bučar ${ }^{1}$, Petra Vizec ${ }^{1}$, Ana Vukres ${ }^{1}$, VEDRAN ŠGGOTA ${ }^{2}$ \& NiNA VuKović ${ }^{2}$}

${ }^{1}$ University of Zagreb, Faculty of Science, Department of Biology, Rooseveltov trg 6, 10000 Zagreb, Croatia

2ZA \& ZAHO herbarium collections, Division of Botany, Department of Biology, Faculty of Science, University of Zagreb, Marulićev trg 20/II, HR-10000 Zagreb, Croatia

Justić, M., Bučar, M., Vizec, P., Vukres, A., Šegota V. \& Vuković, N.: The rare and endangered orchid Cypripedium calceolus L. in Croatia - refound in Gorski Kotar (West Croatia) after 126 years. Nat. Croat., Vol. 29, No. 1., 55-62, 2020, Zagreb.

In Croatia, Cypripedium calceolus L. is an orchid species that is endangered and strictly protected . Most of the findings in Croatia have been made in Mt. Velebit and the Lika region: however, most of the recorded findings are very old, and have not been confirmed in recent times. This paper presents a detailed analysis of all published records of this species in Croatia. Additionally, one new locality of the species was found near Delnice in summer 2019, the second finding of the species in Gorski Kotar, where it was recorded and collected as long as 126 years ago. This is an important finding that confirms the existence of this extremely rare species in Gorski Kotar and Croatia.

Key words: Delnice, flora, IUCN, Orchidaceae

Justić, M., Bučar, M., Vizec, P., Vukres, A., Šegota V. \& Vuković, N.: Rijetka i ugrožena orhideja Cypripedium calceolus L. ponovno nađena u Gorskom kotaru (zapadna Hrvatska) nakon 126 godina. Nat. Croat., Vol. 29, No. 1., 55-62, 2020, Zagreb.

Cypripedium calceolus L. je u Hrvatskoj ugrožena i strogo zaštićena orhideja. Većina nalaza u Hrvatskoj odnosi se na Velebit i Liku, a od svih zabilježenih nalaza u Hrvatskoj otprilike polovica je vrlo stara i nije potvrđena u novije vrijeme. U ovom radu donosi se detaljni pregled do sada objavljenih podataka o rasprostranjenosti ove vrste u Hrvatskoj. Dodatno, tijekom ljeta 2019. godine u blizini Delnica pronađen je novi lokalitet koji predstavlja tek drugi pronalazak te vrste u Gorskom kotaru, gdje je vrsta posljednji put zabilježena i sakupljena prije čak 126 godina. Ovaj važan nalaz potvrđuje postojanje ove iznimno rijetke vrste na području Gorskog kotara i Hrvatske.

Ključne riječi: Delnice, flora, IUCN, Orhidaceae

\section{INTRODUCTION}

Cypripedium calceolus L. is a 20-60 $(-70) \mathrm{cm}$ tall herbaceous perennial orchid, growing in a form of a geophyte. The stem carries 3-5 oval-lanceolate leaves and 1-3 large flowers (Delforge, 2006). Sepals and petals are purple-brown, elongated, more or less twisted 
and with numerous well-defined parallel veins (NiкоLıć, 2019), while the lip is yellow and shaped as a slipper. The species flowers from May to June, in mountain areas as late as in July (Delforge, 2006). It is mainly pollinated by bees of the genera Andrena, Lasiglossum and Halictus, although some small Coleoptera and Diptera can be facultative pollinators (KULL, 1999). Some beetles or caterpillars pollinate but also destroy the plant while visiting or eating its perianth respectively. Fruits are capsules which ripen in September. The seeds are dispersed by wind, rarely by rain (KuLL, 1999).

C. calceolus belongs to the Eurasian floral element and is considered a sub-boreal, arctic, subalpine and mountain species (Nikolić \& Topić, 2005). It prefers rocky, moist, semi-shaded to shaded and moderately warm habitats over limestone bedrock and requires alkaline to slightly acidic and nutrient poor to moderately rich soils (DeLFORGE, 2006; NiкоLić, 2019). The species generally inhabits scrub, open to dense woodland and woodland edges, up to $2000 \mathrm{~m}$ a. s. 1. (Delforge, 2006). C. calceolus is widely distributed throughout Europe and Asia, spread all the way from Great Britain and Scandinavia across northern and central Europe to north-east Spain and northern Italy through southern Siberia. The largest known populations in Europe are found in the West-Estonian Archipelago Biosphere Reserve and in some parts of Poland (KuLL, 1999). In Croatia it mostly inhabits deciduous and mixed woodland of pre-mountain and mountain areas up to $1700 \mathrm{~m}$ a. s. 1 .

In certain parts of its distribution range Cypripedium calceolus is given different levels of threat status. The global IUCN red list describes it as least concern (LC), while the European list treats it as near threatened (NT) (BILz, 2011). National lists treat C. calceolus in various ways, from regionally extinct (RE) in Luxembourg (BILz, 2011), critically endangered (CR) in Bosnia and Herzegovina, Bulgaria, Serbia and the United Kingdom, endangered (EN) in the Czech Republic, Hungary, Russia and Spain, vulnerable (VU) in Austria, Belarus, Denmark, France, Germany, Italy, Lithuania, Slovakia, Slovenia and Switzerland, near threatened (NT) in Finland and Norway and least concern (LC) in Sweden (Šilić, 1996; Stevanović, 1999; Bilz, 2011). According to the Red Book of Threatened Vascular Plants of Croatia (Nikolić \& Topić, 2005), C. calceolus is designated as an endangered species (EN). According to the IUCN, the main threats to this species are collecting from the wild, ecosystem modifications, agricultural \& forestry effluents, logging and wood harvesting (BILz, 2011) and climate change (KolanowsKa \& JaKubsKa-Busse, 2020).

Following its threat status, in Croatia C. calceolus is strictly protected by law (ANONYmous, 2013). This species is also listed on the Bern Convention on the Conservation of European Wildlife and Natural Habitats (Bern Convention) (AnONymous, 1996) and Appendix II of the Habitats Directive (NATURA 2000 Species) (ANNEX II Council Directive 92/43/EEC of 21 May 1992), being protected on the international level as well.

In southeastern Europe, it is known from Croatia, Bosnia and Herzegovina, Montenegro, Serbia and Bulgaria, which is its most south-easterly outpost in Europe (PERRY \& Perry, 2014). There is only one confirmed locality in Montenegro (canyon of the River Tara near Dobrilovina, in Durmitor National Park) found by Stevanović in 1985 and one in Serbia (Suva planina near Niš) reported by Niketić in 1985 (STEvanović et al., 1991). Its occurrence in Macedonia and Greece is doubtful (Stevanović et al., 1991). 


\section{Cypripedium calceolus in Croatia}

Given the number of currently registered records, a quick search through Flora Croatica Database (Nikolić, 2019) could lead us to the wrong assumption that this species is not so rare in Croatia, for most of the references shown here are actually secondary statements, citing very old and mostly unconfirmed records from the past. The only regions where the species has been recently confirmed are the Plitvice Lakes National Park and Mt. Southern Velebit. The historical findings from Žumberak Mt., Koprivnica, Kalnik Mt. and Gorski Kotar have not been confirmed recently.

The first record from the Plitvice region (and generally Croatia) originates from the ZA herbarium collection - Schlosser and Vukotinović collected material from Mrsinj near the town of Korenica in 1852 (ZA6237, Na Merzinu kod Korenice; ZA6240, In monte Merzin ad Korenicam) and published those records in Syllabus florae Croaticae (Schlosser \& Vukotinović, 1857) and Flora Croatica (Schlosser \& Vukotinović, 1869). Additionally, NeILrich (1868) mentioned the nearby locality Prijeboj (Priboj). Later on, these localities were repeatedly cited in the literature as exact toponyms (Rossi, 1913; DegEN, 1936), or more often as Plitvice Lakes National Park (Š́EgulJA \& KRGA, 1990; KRGA, 1992, ŠUgAR, 1994; Volarić-Mršić \& Marković, 1996; Nikolić \& Topić, 2005). Since all these publications were gradually incorporated into the database, adding also the cited $C$. calceolus records, the number of records in the database is currently larger than the actual number of findings. However, it took more than 130 years for species to be re-found in this region, and was recently registered in four localities (KRANJČEV, 1998, 2000, 2005a, 2005b; VERHAART, 2016).

Several historical findings of C. calceolus from Southern Velebit occurred in the literature in the period from 1898 to 1938 and were confirmed later by FORENBACHER (1990) and KRANJČEV (2005a) and more recently by RANDić et al. (2013).

For Mt. Žumberak we have found that the record from Forenbacher (1998) was erroneously included into the database, as this work does not mention C. calceolus at all. On the other hand, the record from Mrøen (1996) refers to Žumberak but does not provide any specific locality. The only record from Žumberak from the literature is from the Slovenian part of Žumberak beneath Logarjev kogel (between Gospodična and Sv. Miklavž) in 1963 (Forenbacher, 1995), and it lies near the very border with Croatia. Given all these data, we have no reliable evidence that C. calceolum has ever been recorded in the Croatian part of Žumberak.

There are only two historical records of C. calceolus from Northern Croatia. One of them, Rasinja near Koprivnica (Schlosser \& Vukotinović, 1857), was cited later in many works (Neilrich, 1868, Schlosser \& Vukotinović, 1869, Šugar, 1994, Volarić-Mršić \& Marković, 1996). However, based on his field survey, KRANJČEv (1994-1995) more recently concluded that the species has long since vanished from this locality. Similarly, the old record of Schlosser (1870) on Mt. Kalnik has never been confirmed (KRANJČEv, 1997).

Finally, the only former record of this species in Gorski Kotar dates back to the $19^{\text {th }}$ century. It was collected by Dr. Lange on June 13, 1893 at the settlement of Kupjak near the town of Delnice (Ad Kupjak pone Delnice) and stored in the ZA collection (ZA6239, Ex herbario Ludovici Rossi). This finding was repeatedly cited in the literature (RossI, 1924; Šugar, 1994; Volarić-Mršić \& Marković, 1996; Nikolić \& Topić, 2005), but without any subsequent confirmation. 


\section{MATERIALS AND METHODS}

The fieldwork was undertaken on $10^{\text {th }}$ June 2019 in Gorski Kotar, a mountain area situated in the western part of Croatia. The climate of the area, according to W. Köppen is temperate humid climate with warm summers $(\mathrm{Cfb})$. Mean temperature of the coldest month is lower than $-3^{\circ} \mathrm{C}$ and the mean temperature of the hottest month is higher than $10^{\circ} \mathrm{C}$ and below $22^{\circ} \mathrm{C}$. Precipitation is uniformly distributed throughout the year, but the least rain falls in the warm part of the year (Š́gota \& Filipčić, 2003).

Standard identification keys were used for the identification of the plant species found on site (Delforge, 2006; Domac, 1994), while the Flora Croatia Database (NikoLIĆ, 2019) was used as a standard for the nomenclature of the species. Due to the fact that $C$. calceolus is very rare and strictly protected by law, no plant material was collected, but the specimens were photographed.

\section{RESULTS AND DISCUSSION}

C. calceolus was found on the north-west slope of Vršek Hill at the elevation $830 \mathrm{~m}$ a. s. 1. The site was located at the forest edge, on the south side of state road D3 between Dedin and Zalesina near Delnice. Two specimens of C. calceolus were found on the site in full bloom, both with two large flowers. Their height was around $30 \mathrm{~cm}$ and they grew at a distance of $10 \mathrm{~cm}$ from each other (Fig. 1). They grew within the association of a Dinaric common beech (Fagus sylvatica L.) and silver fir (Abies alba Mill.) forest. Surrounding vegetation included Abies alba Mill., Acer pseudoplatanus L., Fagus sylvatica L., Aegopodium podagraria L., Aposeris foetida (L.) Less., Aquilegia vulgaris L., Cirsium erisithales (Jacq.) Scop., Euphorbia dulcis L., Homogyne sylvestris Cass., Omphalodes verna Moench. and Taraxacum officinale Weber. It should be stressed out that the rarity of $C$. calceolus in Croatia is rather expected, as the global records of the species are more frequent in suboceanic and subcontinental climates, and accordingly the predicted niche suitability declines toward the south-east of Europe (KolANOwSKA \& JAKUBSKA-BRUSSE. 2020).

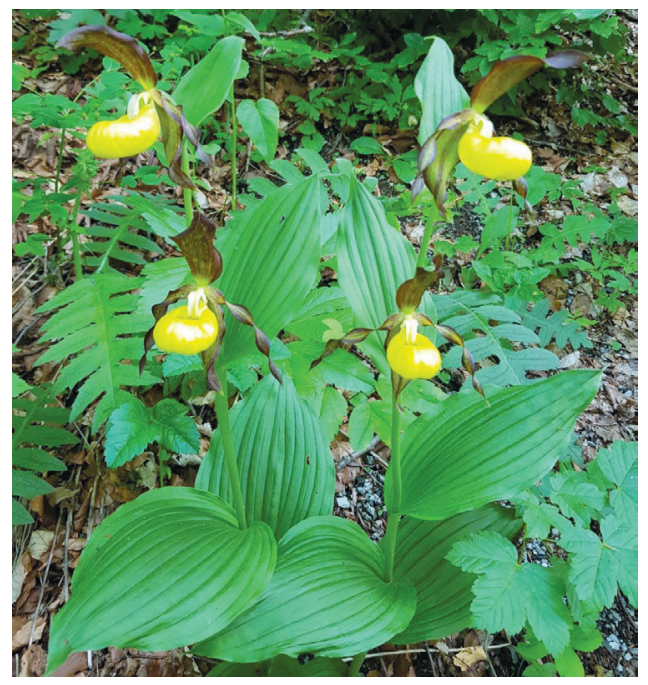

Fig. 1. Specimens of Cypripedium calceolus L. found between settlements Dedin and Zalesina near Delnice (Gorski Kotar, W Croatia) (Photo by P. Vizec) 


\section{CONCLUSION}

The newly found site with C. calceolus between settlements Dedin and Zalesina is, to the extent of our knowledge, the seventh recently confirmed locality of this species in Croatia and second known locality for Gorski Kotar (Fig. 2). Considering the fact that the first record in Gorski Kotar was in 1893, this is an important finding confirming the occurrence of this species 126 years later.

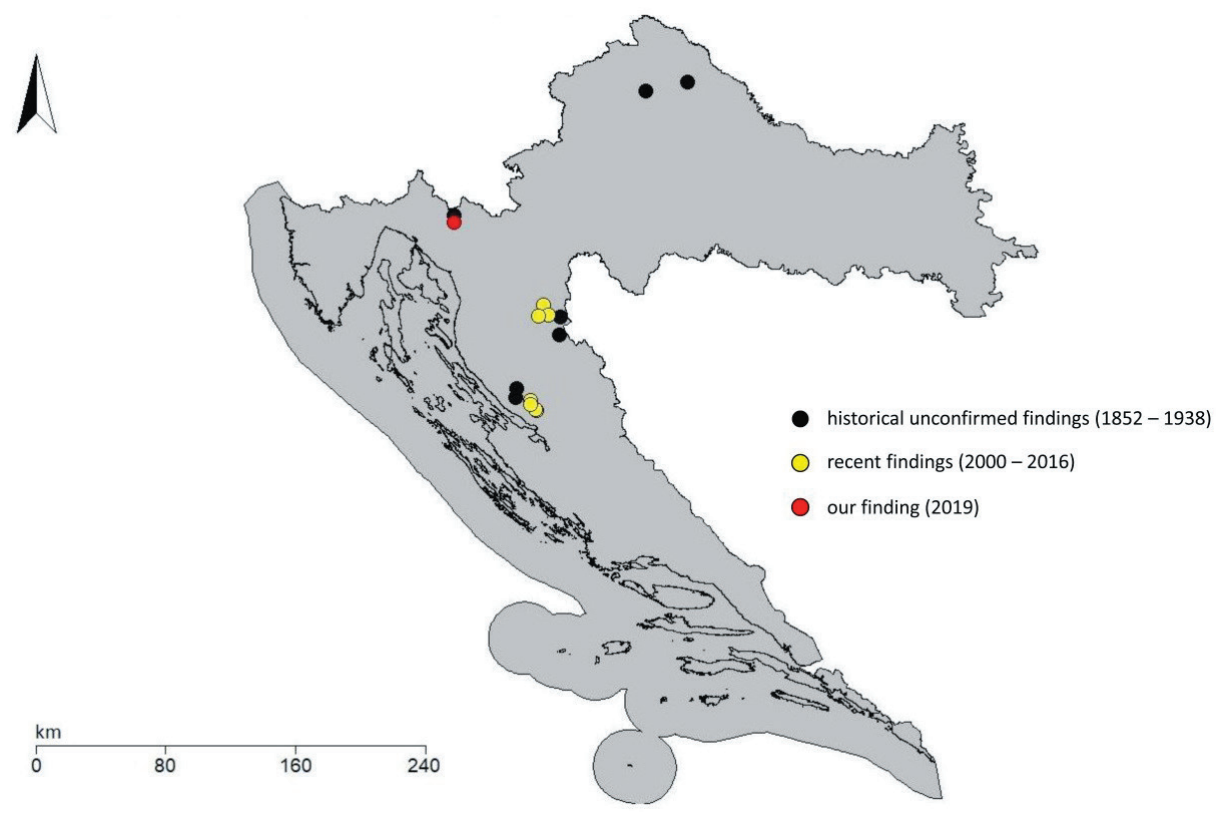

Fig. 2. Distribution of Cypripedium calceolus L. in Croatia.

The newly found site is within five kilometers of the first, historical record. Because of their proximity, the similarity between the two sites is expected to be rather high. Although the historical record was not confirmed in recent times, should the population of $C$. calceolus still persist on this site we assume that these two populations are interconnected through pollinators and winds which disperse the pollen and seeds. Also, all the localities where the species was found are of similar climatic and geological background, which indicates that the species survival and success depends on these ecological factors.

Given the rarity and threat status of this species in Croatia, active conservation and protection measures should be undertaken. In order to preserve the species in Croatia and in nearby countries, more efficient education of the public and stricter site and area protection are needed. Considering the attractive appearance of this plant combined with the lack of knowledge and awareness of the local people, collecting from the wild is the largest threat to this species. If more effort were directed to raising awareness, both in schools and through various media, people would certainly reduce their collecting of plants and probably even help with active conservation. 


\section{ACKOWLEDGMENTS}

We express our appreciation to our colleague Nikola Koletić for his help in designing the distribution map.

Received January 4, 2020

\section{REFERENCES}

Anonymous, 1996: Recommendation No. 49 (1996), concerning protection of some wild plant species which are subject to exploitation and commerce (Adopted by the Standing Committee on 26 January 1996). Convention on the Conservation of European Wildlife and Natural Habitats. Council of the European Communities, 1-7.

Anonymous, 2013: Pravilnik o strogo zaštićenim vrstama (Ordinace of strictly protected species). Official Gazette (OG) 144/13, 7-84.

BILz, M., 2011: Cypripedium calceolus. The IUCN Red List of Threatened Species 2011: e.T162021A5532694, accessed on 4 December 2019.

Degen A., 1936: Flora Velebitica, I. Band. Ungar. Akad. Wiss., Budapest.

Delforge, P., 2006: Orchids of Europe, North Africa and the Middle East. Timber Press, Portland. 301-303. pp 592.

DomAC, R., 1994: Croatian flora. Školska knjiga, Zagreb. 458-460.

ForenbaCher S., 1990: Velebit i njegov biljni svijet. Školska knjiga, Zagreb. pp 800.

Forenbacher S., 1995: Žumberak. Kalendar flore Žumberačke gore. Školska knjiga d.d., Zagreb. pp 653.

Forenbacher S., 1998: Otrovne biljke i biljna otrovanja životinja. Školska knjiga d.d., Zagreb, pp 435.

KolanowsKa, M. \& A. JaKubsKa-Busse, 2020: Is the lady's-slipper orchid (Cypripedium calceolus) likely to shortly become extinct in Europe? - Insights based on ecological niche modelling. PlosONE.

KranjčEv R., 2005a: Orhideje (Orchidaceae) šumskih staništa. Šumarski list 129(7-8), 424-429.

KranjčEv, R., 1994-1995: Crvena knjiga biljnih vrsta Hrvatske - vrste u Podravini, na Bilogori i Kalniku. Ekološki glasnik: časopis o prirodi 4(1-2), 11-16.

KRANJČEV, R., 1997: Neke bioekološke značajke Kalnika. Priroda: časopis za popularizaciju prirodnih znanosti i ekologije Hrvatskoga prirodoslovnog društva 87(845), 22-27.

KranjčEv, R., 1998: Cypripedium calceolus - Field observation. In: Nikolić, 2019: Flora Croatica Database, accessed on 4 December 2019.

KranjčEv, R., 2000: Cypripedium calceolus - Field observation. In: Nikolić, 2019: Flora Croatica Database, accessed on 4 December 2019.

KRANJČEv, R., 2005b: Hrvatske orhideje: prilozi za hrvatsku floru: staništa, svojte, hibridi, zaštita. Agencija za komercijalnu djelatnost, pp 518.

KRGA, M., 1992: Flora Nacionalnog parka Plitvička jezera. Plitvički bilten, časopis za upoznavanje i uređenje Plitvičkih jezera 5, 27-66.

KulL, T., 1999: Cypripedium calceolus L. Journal of Ecology 87, 913-924

MrĐEN, M., 1996: Žumberak- zaboravljena ljepota. Ekološki glasnik: časopis o prirodi 5(3), 6-20.

NeIlrich, A., 1868: Die Vegetationsverhaeltnisse von Kroatien. Verhandlungen der Kaiserlich-Könighlichen Zoologisch-Botanischen Gesellschaft. Wien.

Nikolić, T. \& J. Topıć, 2005 (eds.): Red Book of Vascular Flora of Croatia. Ministry of Culture, State Institute for Nature Protection, Republic of Croatia, Zagreb. 301-303.

Nikolić, T. (ed.), 2019: Flora Croatica Database. Department of Botany, Faculty of Science, University of Zagreb. (http://hirc.botanic.hr/fcd), accessed on 4 December 2019.

Perry, J.M. \& A.M. Perry, 2014: A new locality for Cypripedium calceolus from the Rodopi Mountains, Bulgaria. Journal Europäischer Orchideen 46(1), 31-40.

Randić, M., A. Brkljačić, G. Lukač \& D. Kremer, 2013: New localities of rare NATURA 2000 species: Pulsatilla grandis Wender., Genista holopetala (Koch) Bald. and Cypripedium calceolus L. in the NW Dinarides in Croatia. Natura Croatica 22(1), 95-109.

Rossi LJ., 1924: Građa za floru Južne Hrvatske. Prirodoslovna istraživanja Kraljevine Jugoslavije 15, 1-217.

Rossi, LJ., 1913: Die Plješivica und ihr Verbindungszug mit dem Velebit in Botanischer Hinsicht Die Plješevica und ihr Verbindungszug mit dem Velebit in botanischer Hinsicht - Darin: Systematische Aufzählung der bis jetzt beobachtete Pflanzen. Magyar botanikai lapok 12(1), 37-106. 
Schlosser, J.C.K. \& LJ. Vuкotinović, 1857: Syllabus florae Croaticae. dr. Ludivici Gaj, Zagreb.

Schlosser, J.C.K. \& LJ. Vuкотіnović, 1869: Flora Croatica. Sumptibus et auspiciis academiae scientiarum et articum slavorum meridionalium, Zagreb, I-CXLI, 1-1362.

SCHLOsser, J.C.K., 1870: Kalnička gora sa svoje prirodopisne znamenitosti. Rad JAZU XI.

Stevanović, V., 1999 (ed.): Crvena knjiga flore Srbije 1. Iščezli i krajnje ugroženi taksoni. Ministarstvo za životnu sredinu Republike Srbije, Beograd, 4-566.

Stevanović, V., M. Niketić \& D. LaKušıć, 1991: Chorological additions to the flora of eastern Yugoslavia, Flora Mediterranea 1, 121-142.

ŠEGOTA, T. \& A. Filipčrć, 2003: Koppenova podjela klima i hrvatsko nazivlje. Geoadria 8(1), 17-37.

ŠEGUlJA, N. \& M. KRGA, 1990: Neke florne i vegetacijske osobitosti travnjaka u Nacionalnom parku "Plitvička jezera". Ekološki glasnik: časopis o prirodi 1(7-8), 64-72.

ŠILIĆ, Č., 1996: Spisak biljnih vrsta (Pteridophyta i Spermatophyta) za Crvenu knjigu Bosne i Hercegovine (In Bosnian). Glasnik zemaljskog Muzeja Bosne i Hercegovine u Sarajevu. Nova Serija 31, 323-367.

ŠUGAR I., 1994: Crvena knjiga biljnih vrsta Republike Hrvatske. Ministarstvo graditeljstva i zaštite okoliša, Zavod za zaštitu prirode., Zagreb, 1-522.

Verhart, F., 2016: Cypripedium calceolus - Field observation. In: Nikolić, 2019: Flora Croatica Database, accessed on 4 December 2019.

Volarić-Mršić I. \& LJ. Marković, 1996: Ugrožene biljne i životinjske vrste. Ekološki glasnik: časopis o prirodi 5(1), 43-45. 
